ACTA THERIOLOGICA

Vol. 23, 17: 285-295, 1978

\title{
The Topography and Structure of Motor Nuclei of Medulla Oblongata in the Beaver
}

\author{
Danuta GALERT, Stanisław SZTEYN \& Janusz DYNOWSKI
}

Galert D., Szteyn S. \& Dynowski J., 1978: The topohraphy and structure of motor nuclei of medulla oblongata in the beaver. Acta theriol., 23, 17: 285-295 [With Plates XIX-XXII].

Studies were carried out on sections of the brain stem of beavers aged from 6 to 18 months. The material for the studies was fixed in neutralized formalin, dehydrated in ethyl alcohol, embedded in paraffin and cross-sectioned to $15 \mu$. Sections were stained with Löffler's methylene blue after Nissl. Every other section was taken for examination. The position and structure of motor nuclei of medulla oblongata of the beaver are described in this paper. The discussion includes a comparison of the structure and topography of motor nuclei of medulla oblongata of the beaver with analogical nuclei of other mammals. which shows that there is considerable similarity in the anatomy of these centres in the beaver and nutria. sztyn].

Teachers Training Coll., Dept. Biol., ul. Żolnierska 14, 10-561 Ol-

\section{INTRODUCTION}

The present paper forms a continuation of studies on the central nervous system of the beaver (Castor fiber $\mathrm{L}$ in n a e u s, 1758) and the aim in view was to determine the topography and structure of motor nuclei of medulla oblongata in this mammal.

\section{MATERIAL AND METHODS}

Examination was made of sections including medulla oblongata and pons Varoli of the brain stem of beavers aged from 6 to 18 months. The material was fixed in neutralized formalin, dehydrated in ethyl alcohol, then embedded in paraffin and cross-sectioned to $15 \mu$. The sections were stained with Löffler's methylene blue in accordance with Nissl's method, taking every other section for examination. Description of the nuclei was made from the rear of medulla oblongata in an anterior direction. Documentation of the study consists of micro- and macrophotograps of the preparations.

\section{RESULTS}

Nucleus nervi hypoglossi (nh - Fig. 1, 10) is a long, distinct band of cells situated in the enclosed part of medulla oblongata and at the base 
of ventricle IV, on which $3 / 5$ anterior parts of the nucleus are located. The average length of $n h$ is about $4.5 \mathrm{~mm}$. The posterior pole of $n h$ appears very slightly forwards from the posterior end of nucleus olivaris caudalis, and the anterior pole disappears at a point slightly to the rear of a transverse plane drawn at the level of the anterior pole of this nucleus.

The posterior part of $n h$ is situated on the ventrolateral side of the central canal, below nucleus parasympathicus dorsalis nn. IX et $X$. In cross-sections the posterior part of $n h$ is a uniform band of cells and is similar in shape to a horizontally positioned oval.

In a forward direction the nucleus shifts towards the centre and approaches the suture. Nucleus intercalatus Staderini appears on its dorsolateral side, nucleus paramedianus dorsalis on the dorsoparamedian side and nucleus sublingualis sympathicus on the ventral side. At a distance of about $0.4 \mathrm{~mm}$ from the posterior pole $n h$ divides into two separate groups of cells: ventromedial and dorsolateral. After the central canal passes into ventricle IV the dorsolateral group gradually shifts in a medial direction and is situated above the ventroparamedian group. At a distance of about $1.4 \mathrm{~mm}$ from the anterior pole the two groups combine and $n h$ again takes on the form of a uniform band of cells. After the central canal passes into ventricle IV $n h$ moves away from the suture but continues to be adjacent on the dorsomedial side to nucleus paramedianus dorsalis, while nucleus parasympathicus dorsalis $n n$. IX et $X$ are situated on its dorso-lateral side in this part. The anterior part of $n h$ shifts in a ventral direction and appears as a rounded group of cells.

Nucleus nervi hypoglossi is formed by multipolar cells containing a large amount of coarse-grained tigroid substance. The size of the cells varies within limits of $40-65 \mu$. In addition a small number of fusiform cells measuring from 35 to $65 \mu$ along the long axis, occur in $n h$.

\section{Accessory nuclei of $n h$}

Nucleus paramedianus s. funiculi teretis Jacobsoni ( $n j$ - Fig. 7,14$)$ lies in the enclosed part of medulla oblongata and on the base of ventricle IV. It average length is about $2.6 \mathrm{~mm} .1 / 2$ of the posterior part of the nucleus is situated in the enclosed part of medulla oblongata. The posterior part of $n j$ is situated at a distance of about $1 \mathrm{~mm}$ forwards from the posterior pole of $n h$, while the anterior pole disappears at a distance of about $1 \mathrm{~mm}$ to the rear of the anterior pole of $n h$.

In the enclosed part of medulla obongata $n j$ lies laterally to the central canal. Nucleus parasympathicus dorsalis nn. IX et $X$ is situated 
on its dorsolateral side, but from the ventrolateral side $n j$ is adjacent to $n h$. The anterior part of the nucleus lies above $n h$, and nucleus praepositus Marburgi appears on its lateral side.

Nucleus paramedianus dorsalis is formed by a small number of cells (4 to 16 per section) and in cross-section its shape often varies and is difficult to describe.

Nucleus paramedianus dorsalis is composed of rounded cells with a small amount of fine-grained tigroid substance. The diameter of the rounded cells varies from 16 to $40 \mu$. A few fusiform cells which stain less deeply than the rounded cells and measure from 15 to $50 \mu$ along the long axis are also encountered in $n j$.

Nucleus intercalatus Staderini (nis - Fig. 2,12) is a short band of cells situated in the enclosed part of medulla oblongata at the level of the median part of $n h$. Average length of nis is about $1 \mathrm{~mm}$. This nucleus adjoins $n p$ on the dorso-medial side, and $n h$ on the ventromedial side.

In cross sections the cells of nis are arranged fairy loosely, forming a group similar in shape to a triangle. The base of the triangle is directed laterally, and the peak medially, trusting between $n h$ and $n p$.

Nucleus intercalatus Staderini is composed of rounded cells measuring. from 12 to $18 \mu$ and multipolar cells measuring up to $25 \mu$.

Nucleus praepositus Marburgi (nm-Fig. 4, 13) lies in the dorsal part of the base of ventricle IV. The length of the nucleus is on an average about $3.4 \mathrm{~mm}$. The posterior pole appears at a distance of about $1.2 \mathrm{~mm}$ from the anterior pole of $\mathrm{nh}$, and the anterior pole disappears at a distance of about $2.2 \mathrm{~mm}$ forwards from the pole of that nucleus.

In cross-sections it take the form of a round group of cells. The posterior part of $n m$ adjoins $n p$ from the dorsolateral side, $n j$ from the medial side, and $n r$ from the ventral side. In the median part the nucleus gradually shifts in a ventral direction and is located on the lateral side, also moving towards the bottom of $n p$.

Nucleus praepositus Marburgi is composed of multipolar cells measuring from 24 to $40 \mu$, spindle-shaped cells measuring from 18 to $55 \mu$ along the long axis and round cells from 12 to $24 \mu$ in diameter. The cells contain a large amount of coarse-grained tigroid matter.

Nucleus sublingualis sympathicus s. Rolleri $(n .-$ Fig. 2,15$)$ lies in the enclosed part of medulla oblongata and at the bottom of ventricle IV. The average length of $n r$ is about $3.3 \mathrm{~mm} .{ }^{2 / 3}$ of the anterior part of the nucleus is located at the bottom of ventricle IV. The posterior pole lies at a distance of about $1.2 \mathrm{~mm}$ forwards from the posterior pole of 
nucleus olivaris caudalis. The anterior pole of $n r$ is situated on the level of the posterior pole of nucleus nervi facialis.

The posterior part of $n r$ adjoins $n h$ on the dorsal side. The anterior part of this nucleus shifts in a dorsal direction, adjacent to $\mathrm{nm}$. In cross-sections $n r$ appears as a round group of cells.

Nucleus sublingualis sympathicus is composed of multipolar and fusiform cells containing scanty coarse grains of tigroid substance. The dimensions of multipolar cells vary within limits of 18 to $52 \mu$, and fusiform cells from 30 to $52 \mu$ measured along the long axis.

Nucleus parasympathicus dorsalis $n n$. IX et $X(n p-F i g .1,11)$ is situated in the enclosed part of medulla oblongata and on the base of ventricle IV. The average length of $n p$ is about $6.4 \mathrm{~mm}$. About $2 / 5$ of the posterior part of the nucleus is situated in the enclosed part of medulla oblongata. The posterior part of $n p$ lies at a distance of about $0.5 \mathrm{~mm}$ to the rear from the posterior pole of nucleus olivaris caudalis, and the anterior pole is situated at the level of the anterior end of the nucleus.

The posterior pole of $n p$ seen in cross-sections is a round group of cells situated dorsolaterally from the central canal. Forwards the number of cells in the nucleus increases and $n p$ takes on the form of a transversely positioned oval. The anterior pole is formed by single loosely arranged cells. In the enclosed part of medulla oblongata $n p$ is situated on the dorsal side of $n h$ and over a small part adjoins nis from the ventrolateral side. After the central canal passes into ventricle IV $n p$ moves gradually in a lateral direction and is at first situated dorsolaterally, and later on the lateral side of $n h$. The anterior part of the nucleus is bounded on the ventromedial side by $\mathrm{nm}$. At a distance of about $0.7 \mathrm{~mm}$ from the posterior pole the nucleus separates into two groups of cells - the dorso-medial and ventrolateral. This division can be seen up to the transverse plane drawn at a distance of about $1.6 \mathrm{~mm}$ from the posterior pole of $n p$, and further forwards the nucleus again becomes a uniform band of cells.

Nucleus parasympathicus dorsalis nn. IX et $\mathrm{X}$ is built of fusiform cells measuring from 26 to $52 \mu$, and rounded cells measuring from 26 to $40 \mu$ along the long axis. The cells are filled with a large amount of coarse-grained tigroid. In the median part of the nucleus there are a few multipolar cells of up to $40 \mu$ in size. In the posterior and anterior part of $n p$ fusiform and rounded cells occur in approximately equal amounts, but fusiform cells predominate in the median part.

Nucleus ambiguus (na-Fig. 3,16$)$ lies in the enclosed part of medulla: oblongata and at the base of ventricle IV. The average length of the: 
nucleus is about $6.7 \mathrm{~mm} .1 / 3$ of the posterior part of the nucleus is situated in the enclosed part.

The posterior pole of $n a$ lies at the level of the posterior pole of nucleus olivaris caudalis, and the anterior pole of the nucleus disappears slightly forwards from the anterior pole of nucleus olivaris caudalis.

$\mathrm{Na}$ lies laterally and dorsally from nucleus olivaris caudalis and ventrally and laterally from $n h$ throughout its length. In the enclosed part $n a$ is situated opproximately midway between these nuclei, but on the base of ventricle IV the distance between $n a$ and $n h$ is twice greater than the distance between $n a$ and nucleus olivaris caudalis. The short anterior part of na lies on the posterior part of nof.

In cross-sections the posterior and anterior poles are formed by a round group of cells. The posterior half of the nucleus exhibits numerous narrower and wider parts. At the level of the anterior limit of $2 / 5$ of the posterior part of $n a$, from its ventromedial surface, a group of cells separates and gradually increases in distance from $n a$ and disappears midway along its length. nof appears next in its elongation.

Nucleus ambiguus is composed of multipolar cells measuring from 30 to $60 \mu$, and a few fusiform cells from 25 to $50 \mu$ along the long axis. A large amount of coarse-grained tigroid substance occurs in the cells. Single rounded cells measuring from 24 to $36 \mu$ are encountered in the median part.

Nucleus nervi facialis (nof - Fig. 9, 17) is a long distinct band of cells situated in the ventrolateral part of the base of ventricle IV. The average length of nof is about $3.7 \mathrm{~mm}$. The posterior pole of the nucleus lies at the level of the anterior end of nucleus olivaris caudalis, and the anterior pole disappears minimally forwards from the posterior pole of $n m t$.

The posterior part of nof lies on the dorsolateral side of nucleus olivaris caudalis. In cross-sections the posterior pole of nof is formed by a small group of cells which rapidly enlarges in the anterior direction. At a slight distance from the posterior pole nof divides into two groups of cells-dorso-medial and ventrolateral. At the level of $1 / 5$ of the posterior part nof undergoes further division and from this place is formed by three groups of cells: medial, median and lateral. The median group is markedly larger than the lateral and medial groups. At the level of $1 / 5$ of the anterior part of the cross-section of nof and the number of cells forming it gradually decrease, and this nucleus is situated more dorsally. At a distance of about $0.9 \mathrm{~mm}$ from the posterior pole of nof the division into groups disappears and the anterior part of the nucleus is a uniform band of cells. 
Nucleus nervi facialis is composed of multipolar cells measuring from 25 to $90 \mu$ and fusiform cells measuring from 40 to $65 \mu$ along the long axis. The cells contain a large amount of coarse-grained tigroid substance. In the posterior part of the nucleus there are relatively few fusiform cells, whereas their number increases markedly in the anterior part of nof.

Nucleus accessorius $n$. facialis (naf-Fig. 5,18 ) is a short band of cells situated in the neighbourhood of nof. The nucleus appears at the level of the posterior limit of $1 / 5$ of the anterior part of nof on its dorsal side. The average length of this band of cells is about $0.6 \mathrm{~mm}$. Nucleus accessorius $n$. facialis takes the form of a rounded group of cells when seen in cross-sections.

Nucleus accessiorius $n$. facialis is composed of multipolar cells measuring from 50 to $90 \mu$. The cells contain numerous coarse grains of tigroid substance.

Nucleus n. abducentis (no-Fig. 6, 19) is a small but distinct band of cells situated in the dorsal part of the base of ventricle IV. The average length of no is about $0.4 \mathrm{~mm}$. The posterior pole lies minimally forwards from the posterior pole of nucleus olivaris nasalis. The anterior pole of no disappears at a distance of about $0.9 \mathrm{~mm}$ to the rear of the anterior pole of nof.

Nucleus n. abducentis lies ventrally and laterally from the geniculum of $n$. VII, laterally from nucleus vestibularis lateralis. In cross-sections the posterior and anterior ends take the form of elongated groups of celis, curved in a bow shape near the geniculum. In the median pari in which the number of cells forming the nucleus is greatest, no is rounded in shape.

Nucleus $n$. abducentis is composed of multipolar cells measuring from 25 to $80 \mu$. Coarse-grained tigroid substance occurs in the cells. Scanty fusiform cells measuring from 25 to $40 \mu$ along the long axis are also encountered in the anterior part of no.

Nucleus motorius $n$. trigemini ( $n$ mt-Fig. 8,20 ) is a distinct band of cells situated on the base of ventricle IV and pons Varoli. The average length of $n m t$ is $2.4 \mathrm{~mm}$. The posterior pole of $n m t$ appears at a distance of about $1.7 \mathrm{~mm}$ forwards from the posterior pole of nucleus olivaris nasalis, while the anterior pole disappears at a distance of about $0.4 \mathrm{~mm}$ forwards from the transverse plane drawn on the level of the anterior pole of nucleus olivaris nasalis.

The posterior part of the nucleus lies ventrally from the anterior part of nucleus vestibularis lateralis. The anterior part is situated ventrally and laterally from nucleus mesencephalicus n. trigemini.

In cross-sections the posterior part of $n m t$ has the outline of a round 
group of cells. Forwards the number of cells and cross-section of the nucleus rapidly increase. At a distance of about $0.4 \mathrm{~mm}$ from the posterior pole $n m t$ divides into two groups of cells: dorso-medial and ventrolateral. At a distance of about $0.5 \mathrm{~mm}$ from the posterior pole of the nucleus, the ventrolateral group divides and further in a forwards direction $n m t$ consists of three groups of cells: dorso-medial, median and ventrolateral. At a distance of about $1.3 \mathrm{~mm}$ from the anterior pole of $n m t$ the various groups of cells join up and the nucleus takes on the form of a uniform band of cells. In an anterior direction the number of cells of the nucleus and its section gradually decrease and $n m t$ gradually disappears.

Nucleus motorius $n$. trigemini is formed of mutipolar cells measuring from 40 to $100 \mu$. In the median part of $n m t$ scanty fusiform cells containing a large amount of coarse-grained tigroid substance also occur. The dimensions of the fusiform cells are from 45 to $80 \mu$ along their long axis.

Three bands of cells accompany the posterior part of $n m t$, lying near the nucleus on its ventro-medial, ventral and ventrolateral sides. These bands are on an average about $0.8 \mathrm{~mm}$ in length and are distinctly : ieparated from each other. The posterior poles of the bands appear it a distance of approximately $0.5 \mathrm{~mm}$ forwards from the posterior jole of $\mathrm{nmt}$. The anterior poles disappear at distance of about $1.1 \mathrm{~mm}$ to the rear of the anterior pole of $n m t$.

These bands are composed of multipolar cells from 10 to $40 \mu$ in size and single round cells measuring from 10 to $25 \mu$. There are numerous small grains of tigroid substance in the cell plasm.

Nucleus subtrigeminalis ( $n s$ - Fig. 8, 21) is a short band of cells lying ventrally and laterally from $n m t$. The average length of $n s$ in the animals examined was about $1 \mathrm{~mm}$. The posterior pole appears on the boundary of $2 / 5$ the height of the posterior parts of $n m t$. The anterior pole disappears at a distance of about $0.8 \mathrm{~mm}$ to the rear of the anterior pole of this nucleus.

In cross-sections the posterior and anterior parts are shaped like a small oval group of cells. In the median part of cross-section of the nucleus and the number of cells forming it increase considerably and $n s$ is in this part shaped like an oval group of cells situated diagonally.

Nucleus subtrigeminalis is formed by multipolar cells measuring from 24 to $40 \mu$ and fusiform cells from 18 to $35 \mu$ along the long axes. Cells of $n s$ stain more deeply than the cells of nucleus_motorius n. trigemini, and ontain numerous thick grains of tigroid substance.

In all the centres examined the cells contain a centrally situated nucleus staining only faintly, with a deeply staining nucleus. 


\section{DISCUSSION}

The cytostructure and topography of motor nuclei of medulla oblongata in the beaver do not exhibit any considerable differences from those of the cell structure and situation of analogical nerve centres in other representatives of Rodentia, e.g. in the nutria (S z t e y n, 1961), or even in representatives of other orders - the rabbit (M essen \& Ols z e wski, 1949), horse (Chomiak, 1951; Milart, 1958) and the pig (Chomiak, 1951; Z i oło, 1957), the goat (Chomiak, 1953; W elento, 1956) and cow (Chomiak, 1951). Certain characteristic species features were, however, found in the beaver which require emphasis.

The majority of the motor nuclei of the medulla oblongata in the beaver are situated more towards the medulla than is the case with these nuclei in other mammals. It is only nucleus $n$. hypoglossi which exhibits the revers relations in the beaver - it reaches further forward than in the horse, cow or pig (Chomiak, 1951), goat ( $\mathrm{Chomiak}$, 1953) and nutria (S zte y n, 1961). In the beaver the relatively weak formation of nucleus intercalatus Staderini also deserves mention.

Nucleus $n$. facialis, very similar to the analogical nerve centre in the nutria (S ztey $n, 1961)$ differs fairly distinctly from this nucleus in domestic mammals in which the division into groups is clearly marked and is maintained for a considerable space. In the beaver a short band of cells occurs above the anterior part of nucleus $n$. facialis, described by $\mathrm{Wy} \mathrm{rubow}$ (1901) as nucleus accessorius $n$. facialis. It also occurs in the nutria (S ztye $\mathrm{n}, 1961)$ and cat $(\mathrm{T}$ a be r, 1961), but is absent in certain domestic animals.

Nucleus parasympathicus dorsalis $m n$. IX et $X$ in the baever is far more strongly shaped in the posterior part, which exhibits division into two groups, than in the anterior part. In the majority of domestic mammals the reverse relations are observed. In addition three kinds of nerve cells occur here: multipolar, fusiform and spherical - no such varied cell structure in nucleus parasympathicus dorsalis nm IX et $X$ has been described for other mammals.

In view of the whole of the data on the topography and structure of motor nuclei of medulla oblongata in the beaver it may be stated that these nerve centres exhibit far greater similarity to analogical nuclei of the nutria than of other mammals examined from this aspect. At the present time, on account of the somewhat scanty material for comparative anatomy, it is difficult to state difinitely whether this similarity is conditioned by phylogenetic relationship or by the similar terrestrial-aquatic way of life of these two mammals. 


\section{REFERENCES}

1. Chomiak M., 1951: Jądra ruchowe rdzenia przedłużonego krowy, świni i konia. Annls Univ. M. Curie-Skłodowska, C 5: 373-440.

2. Chomiak M., 1953: Topografia i budowa jąder ruchowych rdzenia przedłużonego kozy. Annls Univ. M. Curie-Skłodowska, DD 8: 181-219.

3. Messen H. \& Olszewski J., 1949: Cytoarchitektonischer Atlas der Rautenhirns des Kaninchens. New York.

4. Milart Z., 1958: Jądra przedniej części rdzenia przedłużonego i mostu Varola konia. Annls Univ. M. Curie-Skłodowska, DD 13: 63-87.

5. Szteyn S., 1961: Topografia i budowa jąder nerwowych rdzenia przedlużonego nutrii (Myocastor coypus Molina). Część I. Jądra ruchowe rdzenia przedłużonego nutrii. Annls Univ. M. Curie-Skłodowska, DD 16: 119-134.

6. Szteyn S., 1962: Topografia i budowa jąder nerwowych rdzenia przedłużonego nutrii (Myocastor coypus Molina). Część II. Jądra czuciowe rdzenia przedłużonego nutrii. Annls Univ. M. Curie-Skłodowska, DD 17: 21-43.

7. Taber E., 1961: The cytoarchitecture of the brain stem of the cat. I. Brain stem nuclei of cat. J. comp. Neurol., 116, 1.

8. Welento J., 1956: Jądra przedniej części rdzenia przedłużonego i mostu Varola owcy i kozy. Annls Univ. M. Curie-Skłodowska, DD 11: 65-107.

9. Wy r u bow N., 1901: Über die zentralen Endingungen und Verbindungen des VII und VIII Hirnnerven. Neurol. Zentralblatt.

10. Zi oło I., 1957: Rozwój jąder ruchowych rdzenia przedłużonego świni. Annls Univ. M. Curie-Skłodowska, DD 12: 75-99.

Accepted, August 22, 1977.

Danuta GALERT, Stanisław SZTEYN i Janusz DYNOWSKI TOPOGRAFIA I BUDOWA JADER RUCHOWYCH RDZENIA PRZEDEUZONEGO
BOBRA

\section{Streszczenie}

Badania zostały przeprowadzone na wycinkach pnia mózgowia bobrów w wieku od 6 do 18 miesięcy. Materiał do badań utrwalono w zneutralizowanej formalinie, odwadniano $\mathrm{w}$ alkoholu etylowym, zatapiano $\mathrm{w}$ parafinie $\mathrm{i}$ krojono na skrawki poprzeczne grubości $15 \mu$. Skrawki barwiono błękitem metylenowym Löfflera wg metody Nissla. Do badań brano co drugi skrawek.

W pracy opisano położenie i budowę jąder ruchowych rdzenia przedłużonego bobra: nucleus n. hypoglossi, nucleus intercalatus Standarini, nucleus paramedianus dorsalis, nucleus sublingualis sympathicus, nucleus praepositus Marburgi, nucleus parasympathicus dorsalis $n n$. IX et $\mathrm{X}$, nucleus ambiguus, nucleus $n$. facialis. nucleus accessorius $n$. facialis, nucleus $n$. abducentis, nucleus motorius $n$. trigemini. nucleus subtrigeminalis. W dyskusji porównano budowę i topografię jąder ruchowych rdzenia przedłużonego bobra $\mathrm{z}$ analogicznymi jądrami innych ssaków. 


\section{EXPLANATION OF PLATES}

Plate XIX

1. Cross-section of medulla oblongata at level of posterior part of nucleus n. hypoglossi.

2. Cross-section of medulla oblongata at level of median part of nucleus n. hypoglossi.

3. Cross-section of medulla oblongata at level of posterior part of nucleus ambiguus.

4. Cross-section of medulla oblongata at level of posterior part of nucleus praepositus Marburgi.

5. Cross-section of medulla oblongata at level of anterior part of nucleus n. facialis.

6. Cross-section of medulla oblongata at level of median part of nucleus n. adbucentis.

\section{Plate XX}

7. Cross-section of medulla oblongata at level of posterior part of nucleus paramedianus dorsalis.

8. Cross-section of medulla obongata at level of median part of nucleus motorius n. trigemini.

9. Cross-section of medulla oblongata at level of median part of nucleus n. racialis. 10. Cells of nuceus $n$. hypoglossi.

11. Cells of nucleus parasympathicus dorsalis nn. IX et $\mathrm{X}$.

12. Cells of nucleus intercalatus Staderini.

\section{Plate XXI}

13. Cells of nucleus praepositus Marburgi.

14. Cells of nucleus paramedianus dorsalis.

15. Cells of nucleus sublingualis sympathicus.

16. Cells of nucleus ambiguus.

17. Cells of nucleus $n$. facialis.

18. Cells of nucleus accessorius $n$. facialis.

\section{Plate XXII}

19. Cells of nucleus n. abducentis.

20. Cells of nucleus motorius n. trigemini.

21. Cells of nucleus subtrigeminalis.

\section{EXPLANATION OF ABBREVIATIONS}

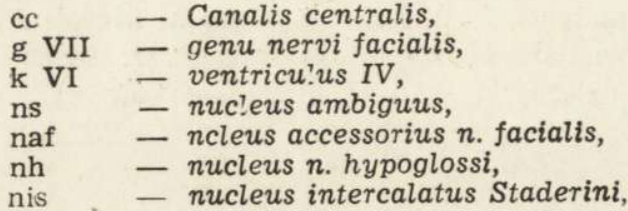




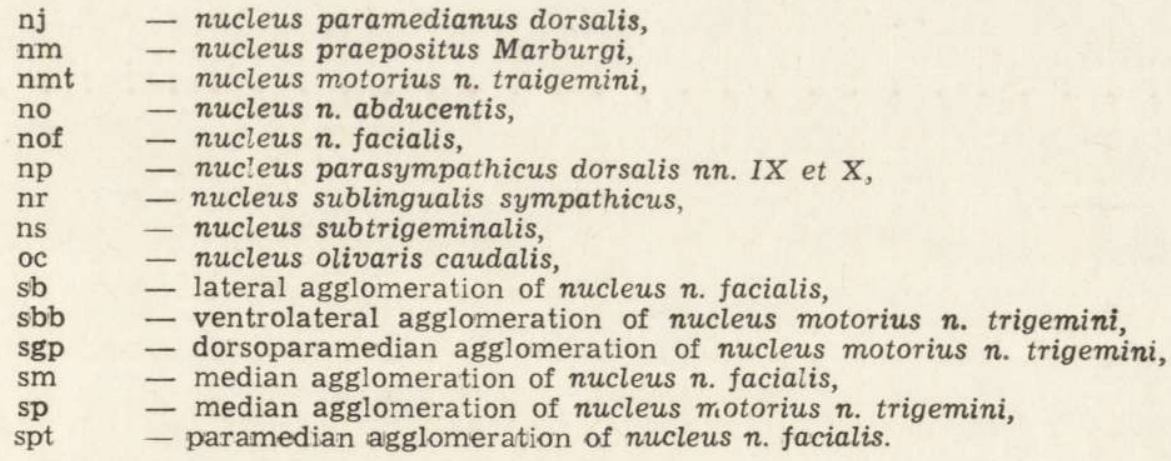




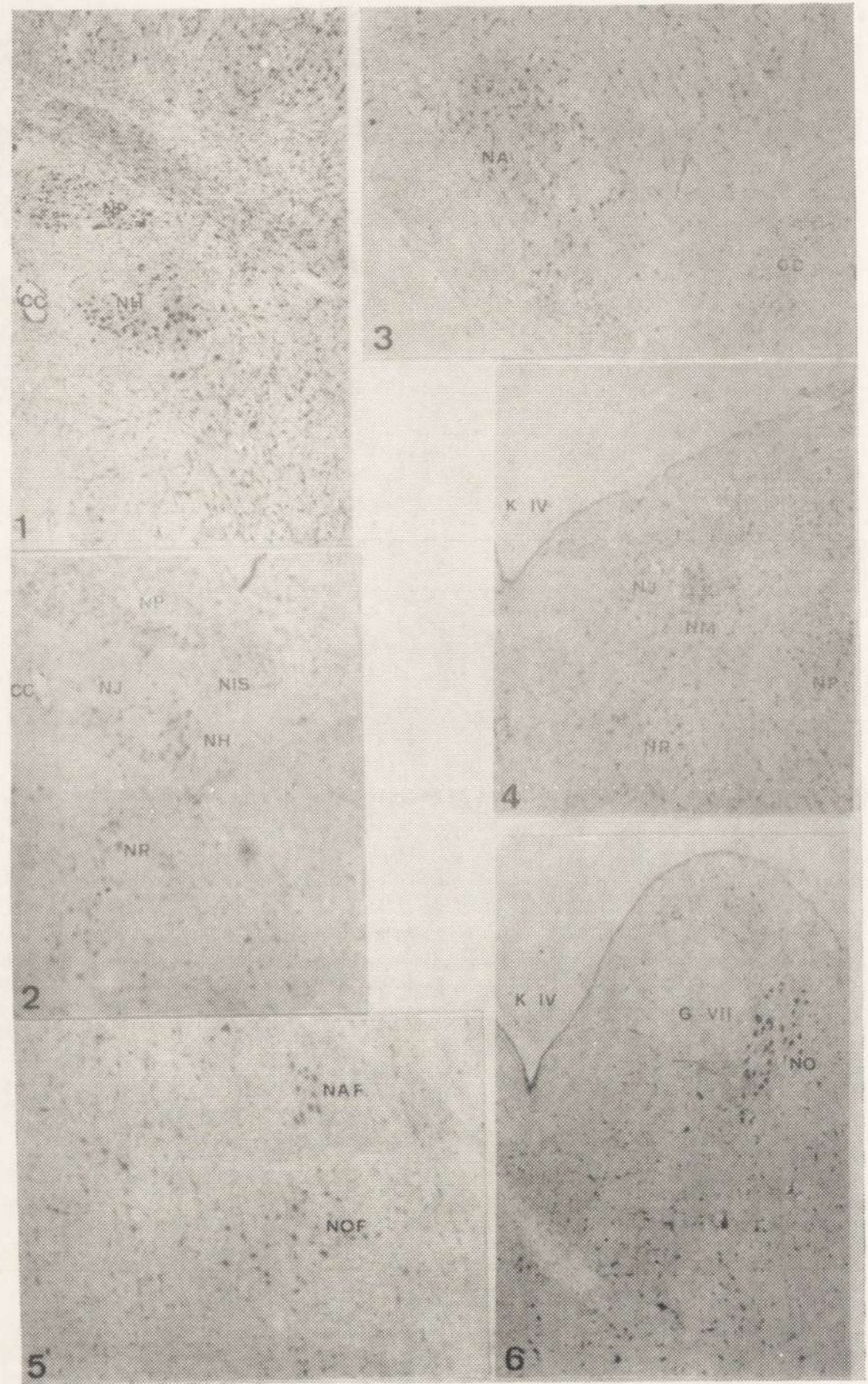




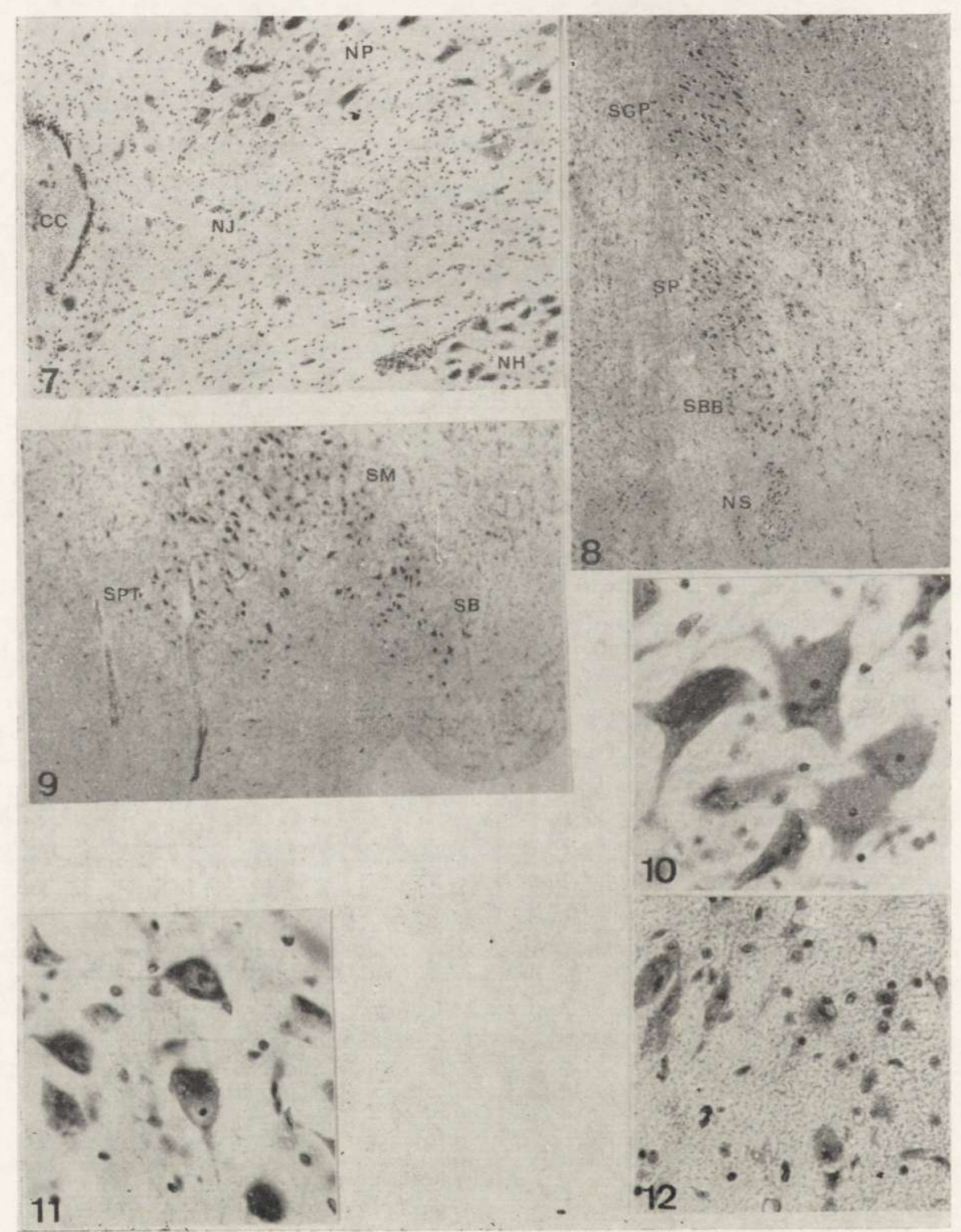

D. Galert et al.

auctores phot. 


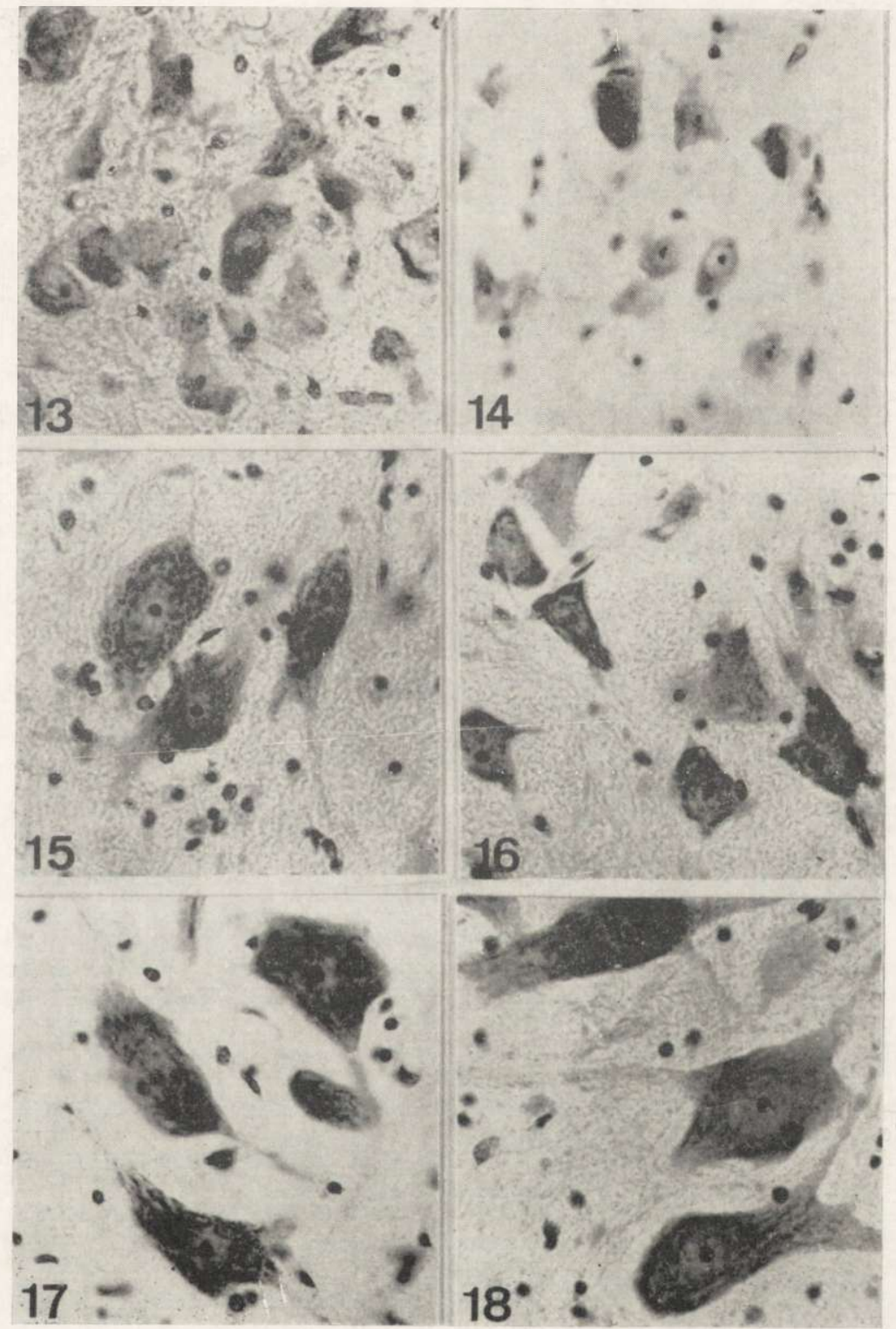

D. Galert et al. auctores phot. 